\title{
The Student Competencies in Information Seeking Behaviour and Using Distance Learning Applications during the COVID-19
}

\author{
Resty Jayanti Fakhlina ${ }^{1}$, Alna Hanana ${ }^{2}$, Lailatur Rahmi ${ }^{3}$, Noor Arief ${ }^{4}$, Heni Nurhaeni ${ }^{5}$ \\ ${ }^{1,4,5}$ Graduate School of Islamic Studies, UIN Syarif Hidayatullah, Jakarta, Indonesia, ${ }^{2}$ Communication \\ Science Department, Andalas University, Padang, Indonesia, \\ ${ }^{3}$ Library Science Department, UIN Imam Bonjol, Padang, Indonesia \\ *alna@soc.unand.ac.id
}

\begin{abstract}
Corona Virus Disease or COVID-19 has become a pandemic that has spread in Indonesia since March 2020. One of the most significant impacts has occurred in the learning process within the university with the presence of the e-learning concept through distance learning systems of networks and digital-based. Distance learning has increased information retention and improved the skills of the academic community in using various applications used in the learning process. Displacement of learning methods that are so fast will also provide less conducive conditions and thus become a challenge in educational institutions. This research was conducted to describe the ability of students in information retrieval and the use of several applications, the majority of which are used in the learning process at one of the faculties at UIN Imam Bonjol Padang. The research method was carried out through the distribution of online questionnaires related to the effectiveness of the implementation of distance lectures, the constraints experienced, and the ability to use applications that are used from the student's perspective. The results show the ability of students in searching electronic information and the use of applications that are commonly used, in this case, Google Classroom, Zoom, and WhatsApp. The results showed that $82.9 \%$ of FAH students disrupted the WhatsApp Group application as a flexible application in utilizing digital learning media.
\end{abstract}

Keywords: Distance Learning; Information Seeking Behaviour; Information Technology; COVID-19; Islamic Higher Education

\section{Introduction}

The use of information and communication technology in the learning process continues to increase and is very promising in improving learning outcomes. In Indonesia, more than 530,000 schools have been closed during the COVID-19 outbreak, affecting 68 million students from pre-primary to tertiary levels and making the need for effective use of technology and continuing to provide pressure. This situation forces a very rapid and widespread increase in the use of media technology in Indonesia in the learning process, which is expected to have lasting effects, especially in the learning process in tertiary institutions. 
Allah SWT says, in Surah Al-Mujadalah Verse 11:

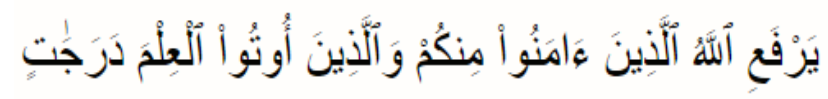

"Surely Allah will exalt those who believe among you and those who are given some degree of knowledge."

In Tafsir Al-Mukhtashar/Markaz Tafsir Riyadh, under the supervision of Shaykh Dr. Shalih bin Abdullah bin Humaid (Imam of the Grand Mosque) that Allah elevates the degree of an expert with many degrees in merit and degrees of good pleasure[1].

Besides that in Surat At-Taubah Verse 122:

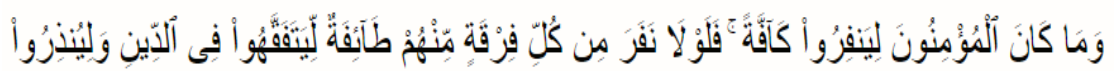

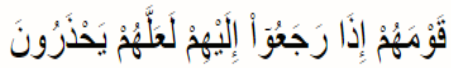

"It does not fit for all believers to go (to the battlefield). Why not go away from each group among them some people to deepen their knowledge of religion and to warn their people when they have returned to them so that they can take care of themselves. "

In the Al-Muyassar Tafsir/Ministry of Religion of Saudi Arabia that Muslims need religious understanding in all matters. Then believers should not be able to wage jihad entirely and leave other Muslims without any faqih who can be chosen by the imam to teach religious affairs. But every army should consist of messengers from each tribe, and some people remain to learn the knowledge of the Shari'a, and to give lessons and warnings to the troops when they have returned to their land so that they fear the punishment of God if they disobey His commands[2].

According to Hamzah Djunaid in his article entitled "The Concept of Education in the Qur'an" concluded that education according to the Qur'an was formulated as a planned and gradual effort to provide knowledge, skills, and mental attitudes to students as provisions in carrying out their duties as servants and caliphs of God on earth[3]. Based on some of the verses above, it has become our primary obligation as Muslims to study. Although the current pandemic disaster is happening, it is not a reason to make us Muslims stop in seeking knowledge.

Corona Virus Disease or COVID-19 has become a pandemic that has spread in Indonesia since March 2020, with the most rapid and epidemic spread to 185 countries in the world[4]. The World Health Organization provides one way to avoid the spread of this stock by limiting work and closing public facilities. COVID-19 cases based on data from the Ministry of Health of the Republic of Indonesia dated July 4, 2020, reported that there were 62,142 positive cases spread in 34 provinces in Indonesia. One of them is West Sumatra with the number of cases to date as of July 42020 , 762 people have been confirmed positive. It is undeniable that the current condition also has a very significant impact on the field of education, especially for tertiary institutions in West Sumatra.

Distance learning is online learning that utilizes information technology, where students try to tackle multiple tasks and decision making at all times. One of the goals of online education is to maximize the decisions students have made online by being given knowledge 
of the correct answers and additional information that can be accessed at any time[5]. It is beneficial for students as students who interact in online programs, one of which can improve student performance. Students can efficiently conduct discussions that focus on learning topics such as a face-to-face class in class[6]. The most prominent characteristic of online learning is that it provides convenience and flexibility for lecturers and students, especially to determine online learning schedules with no regard for location[7].But because of the lack of promotion and socialization in its application, this application has not been used optimally. The majority of the learning process, in fact, uses more zoom, Whatsapp group, and google classroom for lecturers and students in carrying out distance learning.

Based on these conditions, Eka Putra Wirman as Rector of UIN Imam Bonjol Padang, in Circular Letter Number B-660 / Un.13 / R / KS.02 / 03.2020, said that UIN Imam Bonjol Padang should conducted lectures and supervised final assignments at all levels of education from D3, S1, S2 to S3 with lecture mechanism and remote guidance through available online platforms, such as whatsapp group, email and google classroom or others. The step was taken as an effort to anticipate and prevent the spread of Coronavirus Disease 2019 (Covid-19) in the campus environment.

Whatever information technology is used, basically the result expected from remote learning is the maximum learning material arrived. Again, the learning process is a process of delivering messages, or we can also call it an act of communication. Communication can be interpreted as a systematic process of exchanging information between parties, usually through a conventional symbol system. Scientifically communication can mean the process of delivering messages or information from the sender to the recipient with certain symbols. The process of delivering this message is very easy with the help of technology. Communication technology is considered to include a broad understanding, including systems, channels, hardware and software of modern communication. At the same time, information technology is part of the understanding of communication technology. Information technology is the science needed to manage information so that information can be searched quickly and accurately. Information can be said as data that has been processed. The data or information can be in the form of text, sound, images, videos and so on.

Based on the two terms above the data concluded that Information and Communication Technology (ICT) is the process of delivering information through data processing that involves sending and receiving information using certain symbols[8]. ICTs are various aspects involving technology, engineering and management techniques used in the control and processing of information and its use, computer relations with humans and matters relating to social, economic and cultural[9]. Utilization of technology and communication in the field of education, such as the use of computers and computer networks provides an opportunity for every learner to access learning material that is presented anywhere and at any time.

The learning process using information technology has actually been carried out at the Adab and Humanities Faculties in several subjects. The Covid-19 pandemic period brought even further influence, both lecturers and students in a short time required to be able to adapt quickly in distance learning. However, in its implementation, it is certainly not as easy as imagined, in fact, several obstacles are present when this distance learning method is applied mainly to the study programs at the Adab and Humanities Faculties.

Information and Communication Technology Media has a significant impact on the learning process at the Faculty of Adab and Humanities of UIN Imam Bonjol Padang. Because seen from one of the competencies of study program graduates is to produce graduates who can carefully adapt to the digital world. Therefore the use of digital technology needs to be integrated into the learning process. Looking at this phenomenon, this study aims to describe 
the competencies of students in electronic information retrieval and the use of various digital applications, the majority of which are used in the learning process at the Faculty of Humanity and Humanities of UIN Imam Bonjol Padang. The media of choice for study are the most widely used by lecturers and students based on observations and interviews in preliminary studies, namely Google Classroom, Zoom, and WA Group.

One of the most popular theories among information science or information behaviour researchers is the theory of David Ellis. David Ellis developed the theory of information search behaviour that was conveyed directly by searching for information systems. Ellis researched scientists who were carrying out daily activities, which were looking for literature, accessing the field or laboratory, writing papers, and so on[10].

Information seeking on the internet not far from using a search engine. The search engine is a computer program in the form of a search engine provided to search for information through keywords available in internet-based information technology. In the Information Skill module of Zayed University, Oxford quoted by Purwono said that $41 \%$ of searchers use Google and the remaining 27\% use Yahoo as the main search engine. With this tool, the user can make it easier to get information in a variety of sources and languages.

Problems in using or disseminating information without mentioning the source are considered plagiarism. On the internet, it is not uncommon to find information that is an exact copy (copy-paste) from another site. Information users need to be careful with such information because its validity is also questionable. Ease of copy-paste also makes information seekers "unconsciously" plagiarized[11].

Information retrieval in this study describes the information behaviour of someone involved in identifying the need for information, finding and using or transferring that information. Ellis in Meho[12] groups these activities into Starting, Chaining, Browsing, Differentiating, Mentoring, and Extracting. Technology has a significant role in distance learning. But the situation and condition of each student are not the same. This causes psychological stress or hedonism towards the students in the learning process.

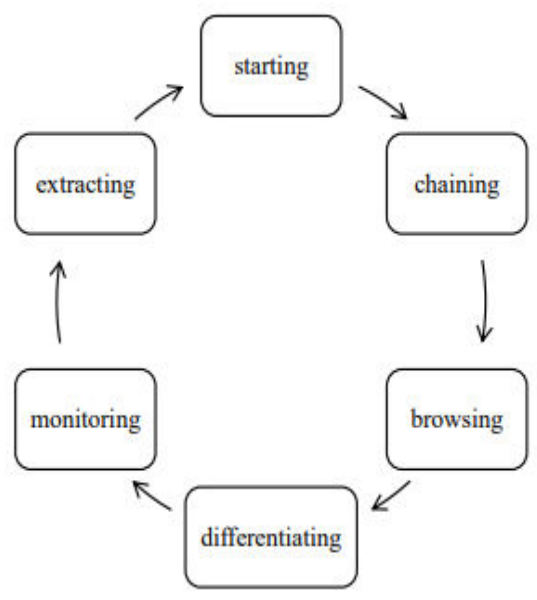

Figure 1. Information Search Behavior Model

Hedonic theory, or psychological hedonism theory, is the idea that human behaviour is motivated by the pursuit of pleasure and avoidance of pain (or, more precisely, displeasure). 
Driven by limited variance in information retrieval behaviour explained by cognitive variables, researchers have begun to explore the potential of hedonic theory. The data show that surfing pleasure (which partly reflects the pleasure of obtaining scientific information online), affective associations (pairing ideas with positive or negative descriptors), and the rankings of pleasure-displeasure obtained during information retrieval are significant correlations and predictors of scientific information retrieval behavior[13].

Lecturers and students have an important role to play as controlling the process of searching for scientific information and distance learning in the network. This digital technology-based learning model can later become one way to improve the quality of teaching and to learn at Islamic tertiary institutions. It can be a need to provide a better learning experience if it is supported by qualified communication and information technology facilities.

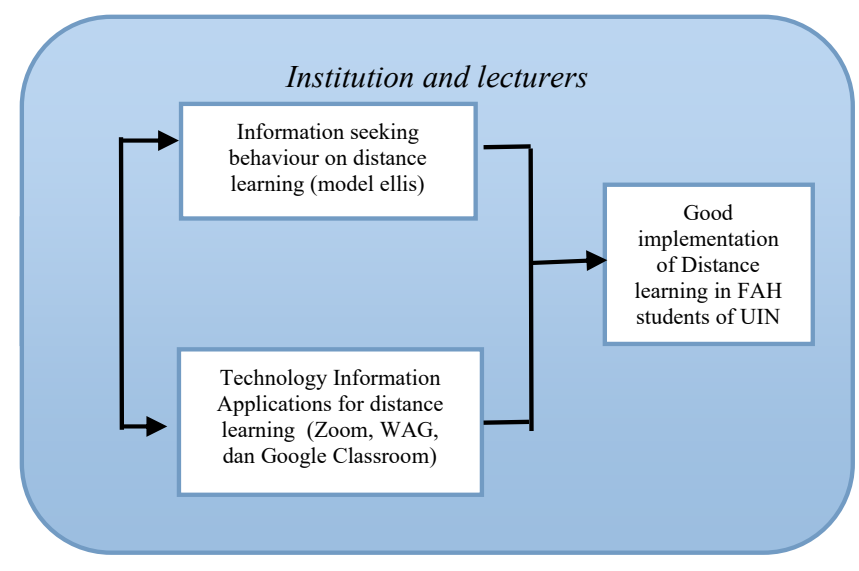

Figure 2. Frame of Mind

Thórsteinsdóttir investigates the information-seeking behaviour of library science students conducting distance learning and staff members at the University of Sweden. His study revealed that geographical distance has a significant influence on the acquisition of literature and the use of information retrieval even in the online environment; that distance learners often experience problems with finding information and mastering information seeking techniques, and with the use of technology; and there is a relationship between access to library services and the use of high-quality resources.

Boardi and Letsolo conducted a study of information needs and information-seeking behaviour of distance students in Lesotho. The study found that overall the majority of respondents were satisfied with their sources of information, but mainly relied on information that was easily accessed. In Botswana[14][15], the Oladokun study found significant evidence that students' information needs were not significantly met, that printed sources, especially books, were the most widely used source of information formats, that neither the level of study nor location had a significant effect on the format of student choice of information sources and that a large number of them depend on their lecturers and colleagues to provide information.

Moyo and Ellysa[16] conducted a survey to find the attitudes of distance learners on the quality and use of information resources and services available at Penn State World Campus. Internet resources and electronic libraries are preferred over traditional library resources by 
most respondents. Tang and Tseng[17] studied information literacy skills in distance learning students, with an online survey of 3517 students in distance learning courses at an American state university, but with a response rate of only $6.2 \%$ (219 responses) and found that students with a level of high trust in information.

The uniqueness of this study from previous research is to describe the ability of students to adjust to facing distance learning during the Covid-19 pandemic: student readiness to withstand changes in learning methods in a short time, the ability to search information through the internet with various channels and the use of several applications in the learning process that is most widely used.

\section{Methodology}

The research method used is a quantitative descriptive approach due to field conditions by distributing questionnaires online using google form. The study population was active students of the Faculty of Adab and Humanities of UIN Imam Bonjol Padang. This population will then be generalized, so this research will be conducted on a portion of the population as well as a sample in this study. The sampling technique is using the Proportionate Stratified Random Sampling method. Determination of the sample size in this study using the Slovin formula with a sample confidence level of a population of 933 students of the Faculty of Adab and Humanities UIN Imam Bonjol Padang with an error rate of 10\%-15\%[18]. Then the sample consisted of 38 students of Arabic Literature, 40 students of History of Islamic Civilization and 39 students of Library Science.

\section{Results and Discussion}

The COVID-19 pandemic encouraged many universities to quickly and comprehensively adopt online learning, distance learning models, and other activities to help control the spread of the virus. Technological progress challenges educational institutions to adapt ways of teaching and learning during this pandemic. Education moves from a knowledge transfer model to a collaborative model that helps the academic community improve knowledge and develop digital skills in the learning process.

It takes a capable electronic information retrieval ability for students as capital in meeting information needs during distance learning takes place. This study will illustrate the ability of students in terms of information retrieval. Analysis of the data in this study uses descriptive analysis, namely statistical analysis that serves to describe or give an overview of the object under investigation.

\section{A. Distance Learning Guidelines at UIN Imam Bonjol Padang}

The Common Wealth of Learning (COL)[19] has supported the government and educational institutions since 1987. COL has developed 'Guidelines on Distance Education during COVID-19 to help governments, educational institutions, parents, and students effectively deal with this crisis so that no one is left behind. This guide issued several guidelines for the administration of education during the Covid-19 pandemic. The main elements emphasized in distance education are: 
1. Learning resources; content is designed to support independent learning, easily accessible to students with a variety of technological media.

2. Pedagogy; Teaching and learning are based on sound pedagogical principles of guideddidactic conversation[20]. The students need to be guided to develop independent learning skills periodically to get the maximum benefit from distance learning.

3. Learning support; Providing psychological and emotional support to learners at a distance alongside continuous academic interactions are keys to student success. Caring human support at a distance facilitates self-directed learning, reduces student isolation, and creates an environment for student engagements in learning[21].

4. Administration; Distance learning can be carried out effectively if it is managed with efficient and accountable administration.

Higher education institutions, especially UIN Imam Bonjol Padang in carrying out distance learning, need to pay attention to the guidelines issued by this COL. UIN Imam Bonjol can adopt important points of existing guidelines following the needs of the institution. The picture above is a summary of some specific guidelines for institutions in implementing distance learning:

1. Develop and implement a good strategy for technology media access following the needs of students.

2. Facilitate the design and development of blended learning environments (Cleveland-Innes, \& Wilton, 2018). Develop a good Learning Management System to support teaching and learning in achieving expected learning outcomes.

3. Prioritize the development of staff capacity to carry out distance learning, and form a specialist unit tasked with identifying broad capacity development for institutions that are sustainable and resilient in implementing learning

4. Share program content developed through institutional repositories to facilitate access to the academic community by anyone, anywhere and anytime

5. Orient students effectively in online learning and develop independent learning skills by creating exciting learning methods.

6. Providing appropriate technology support. Technology failures can interfere with learning, so institutions must determine various ways to provide distance learning support.

The same guidelines apply to students so that UIN Imam Bonjol Padang students can adjust well in distance learning. It is necessary to pay attention to the instructions of this COL. The following guidelines were issued by COL and tailored to UIN Imam Bonjol Padang:

1. Develop skills for online learning and become independent learners by mastering skills in digital information retrieval

2. Engage in group learning activities, adjusting study groups to stay connected with peers

3. Manage the distance learning schedule properly to manage time effectively

4. Stay connected with the lecturer regularly and other friends usually via telephone, social media and learning systems.

5. Develop essential skills to understand the consequences of plagiarism, privacy issues and the negative impact of misinformation in the digital space.

6. Student organizations play a central role in supporting distance learning and provide support to new students to recognize forms of distance learning through light discussion and guidance.

B. Distance Learning Applications Used by UIN Imam Bonjol Padang Student

This study limits the focus on distance application used in the learning process in the zoom application, whatsapp group, and google classroom. This is because these three applications are 
the three applications that are most widely used by FAH UIN Lecturers and Students Imam Bonjol Padang in conducting distance lectures. Based on the questionnaire that has been distributed to students, it can be seen that most of them are aware of the application. This is because some of the courses they take in the even semester 2019/2020 use these applications in distance learning. The comparison of the zoom application, whatsapp group, and google classroom looks as follows:

The most popular application choice is WhastApp Group seen from the answers of respondents in $56.7 \%$ agree, and $34 \%$ strongly agree. For the google classroom application, respondents stated agree as much as $57.1 \%$ and strongly agreed $15.7 \%$. While the Zoom application is only around $46.4 \%$ which says it is accessible and applicable. This happens because the whatsapp group is an application that is commonly used daily by students before the Covid-19 pandemic. While the other two apps, only used when the Covid-19 pandemic takes place in the learning process.

For internet network conditions, the zoom application is considered as an application that is difficult to use when dealing with a weak internet network. For network problems, WhatsApp has advantages for students because it can work on various types of networks, even though only $2 \mathrm{G}$ networks, as many as $31.9 \%$ strongly agree and $52.5 \%$ agree. WhatsApp Group is in high demand by FAH students of UIN Imam Bonjol Padang because more than $75 \%$ of students go back to their hometowns during COVID 19. Conditions in many areas outside Padang City experience scarcity of internet networks and are usually only supported by one provider. Some students even have to climb the hill to get a signal, or some of them go to the local city. For the Zoom application, dominant students said they disagreed, disagreed, and strongly disagreed $(50.7 \% ; 20.3 \%$; and $12.3 \%)$ of the internet connection to the application. While the Google classroom application is between zoom and Whatsapp group according to the choice of students based on a good internet connection, which is strongly agreed $7.9 \%$; agree $39.3 \%$; disagree $40.7 \%$; disagree $9.3 \%$; strongly disagree $2.9 \%$.

Wasteful use of internet quota is dominated by zoom, about three credit hours of courses spend 2 GB quota. The use of a small internet quota for the zoom application was answered disagreeing, disagreeing, and strongly disagreeing by $82.6 \%$ of FAH students of UIN Imam Bonjol Padang. While the use of WhatsApp group is considered as the cheapest application, it is stated that it was agreed and agreed by $79.6 \%$ of FAH students of UIN Imam Bonjol Padang. And google classroom as many as more than half of FAH students of UIN Imam Bonjol Padang $(51.8 \%)$ consider it an internet quota saving application.

The application that makes it easy to carry out the learning process according to students is the WhatsApp Group application (76.1\% chose strongly agree and agree), then followed by google classroom (58.1 chose strongly agree and agree). Furthermore, the zoom application is the least, no, and absolutely not approved by FAH students of UIN Imam Bonjol Padang is an application that facilitates and implements the learning process, which is $59 \%$.

Furthermore, the application that is considered to provide significant benefits in the learning process is the WhatsApp Group application (74.5\%) - followed by google classroom and zoom. Likewise, with learning activities and doing assignments at any time when students have free time, the preferred student is WhatsApp Group (75.3\%). The selection of the Whatsapp Group application is also the first choice (78\%) of FAH students of UIN Imam Bonjol Padang when connected to the internet in studying and doing assignments. According to FAH students of UIN Imam Bonjol Padang, the WhatsApp Group application is also considered a flexible use in utilizing digital learning media (82.9\%).

The dominant choice of FAH students of UIN Imam Bonjol Padang students to WhatsApp Group is due to the familiarity and simplicity of the application for students. Besides, 
WhatsApp Group also saves quota and is easily accessed even if it is on a $2 \mathrm{G} / 3 \mathrm{G}$ network. Nevertheless, students generally are not satisfied with distance learning by using any application. They prefer to do face-to-face learning. This is due to the unpreparedness of students to carry out distance learning suddenly. Other factors also come from the geographical location of students who have difficulty reaching the internet network and the high cost of data packages so that students are overwhelmed in participating in distance learning.

\section{Information Seeking Behavior of UIN Imam Bonjol Padang Students}

Technological progress challenges educational institutions to adapt ways of teaching and learning during this pandemic. Education moves from a knowledge transfer model to a collaborative model that helps the academic community improve knowledge and develop digital skills in the learning process. One of the abilities needed by students is in searching for electronic information. So it can be capital in meeting information needs during distance learning takes place.

Students of the Adab and Humanities Faculty need to be given guidance to be able to search for information well. If analyzed based on the results of data processing through the Ellis model related to information-seeking behaviour, it appears that 1) Starting: only 67\% of students determine the type of information before searching and only $65,2 \%$ used effective search strategies. 2) Chainging: $78.8 \%$ searching for data sourced from specific reference sources, 3) Browsing: about $74.6 \%$ searching according to topics related to needs, 4) Differentiating: $70.8 \%$ stated that participants evaluated the search results, 5 ) Monitoring: only $69.6 \%$ of respondents pay attention to the renewal of information and $76.1 \%$ who filter information from books or other readings if they find different information from the internet, 6) Extracting: $69.3 \%$ of respondents use search results in making assignments lectures.

It can be seen from the results of the data processing that the information retrieval ability of the Adab and Humanities Faculty students is still at a moderate stage. If analyzed from the three groups of respondents, there is a significant difference between the ability of Library Science students with Arabic Literature and the History of Islamic Civilization. For example, the Starting indicator shows that $67 \%$ comes from $38 \%$ of library science students, $25 \%$ of the History of Islamic Civilization and $10 \%$ of Arabic Literature Language. This is also reinforced based on the researchers' continued observation that this happened because D3 Library Science students were provided with material related to Scientific Information Search in the subject of Information Reference Services and Information Literacy.

In addition to the course in class, students can also master the Competency of Information Search through User Education/Guidance activities by the university library. Changes in educational patterns increase the need and urgency of User Education/Guidance. Mastery of information retrieval techniques or electronic information resources is essential given in the user education activities section (Jain 2006). Research conducted by Bainton (2001) has shown that library user education has a positive impact on the quality of information retrieval[22].

The UIN Imam Bonjol Padang Library currently provides e-repositories as a means of information resources for the academic community. In the current pandemic, students can take advantage of institutional repositories, where all information needs during the pandemic can be fulfilled. This service certainly provides full access rights for UIN Imam Bonjol Padang students. The library can be a solution for students who get assignments from lecturers and need references. 


\section{The readiness of UIN Imam Bonjol Padang Students in Facing the Distance Learning Process}

This study also found that there were obstacles in the process of searching this information. Based on preliminary data and interviews with several students, $60 \%$ of students had difficulty in tracing accurate electronic information in fulfilling lecture materials and assignments. Unlimited open access from a variety of electronic information sources, making students freely explore without knowing the accuracy of the information, especially for religious sources. Then, another obstacle that arises is $55 \%$ of students in rural areas do not have good internet connectivity, and $30 \%$ of students with low-income backgrounds experience barriers to internet network access and result in not having access to the tools needed to use distance learning media in the network. The lack of digital literacy, low costs, and limited connectivity in remote areas and the speed of electronic information retrieval become another negative side which certainly only complicates the online learning process for some groups of students.

Various obstacles in the process of finding information in distance lectures carried out by UIN Imam Bonjol Padang finally show the level of readiness of students in facing changes. Based on research data, students stated that they experienced a relatively high stress level. The behavior of searching for scientific information that has not been mastered becomes a big obstacle for students. Excessive anxiety, fear and worry because of the demands to adapt to the digital environment so quickly that it has difficulty in the learning process. This is shown by the results of a sample questionnaire from active students of the Adab and Humanities Faculty of UIN IB Padang, that respondents showed $65.5 \%$ anxiety and stress when this change emerged, lack of support from academic supervisors at $54.9 \%$ and respondents felt readiness institutions that are not optimal at $51.4 \%$. This is because educational institutions and the academic community are forced to adjust in a concise time. This unpreparedness causes the effects of boredom, boredom, and psychological disorders due to the demands of different learning methods than usual.

Psychological disorders known as psychosomatic disorders. Psychosomatic Disorders, according to Ahmad Zain in his article entitled "Psychosomatic and Al-Qur'an Based Psychological Approaches" says that psychosomatic disorders are traditionally defined as physical illnesses that are influenced by psychological factors. Psychosomatic disorders do not include psychological factors that are too heavy to be classified into mental disorders, but this disorder is very influential in influencing medical disorders. One of the causes of this psychosomatic disorder is the emotion which is symbolically transformed into a particular physical disorder. For example, if a person is anxious, complaints from the heart and vice versa, hate can cause vomiting (Sarnoto, 2016)[23].

Efforts made for someone with psychosomatic disorders is to provide full support to the sufferer, both in the family and specifically in this case, the lecturer. Supervising lecturers have a significant contribution to their students, with changes in current learning methods, supervisors can open a consultation room outside the subjects they are teaching.

\section{Conclusion}

The research on the distance learning process at UIN Imam Bonjol Padang shows that three applications are most widely used, Whatsapp, followed by Google Classroom, then Zoom. In all categories, Whatsapp remained superior and became the primary choice of students both in terms of internet stability, quota usage, ease of access, benefits gained and 
familiarity. Furthermore, research also shows that the ability of information retrieval of students of the Adab and Humanities Faculty is still at a moderate stage. The lack of digital literacy, low costs, and limited connectivity in remote areas and the speed of electronic information retrieval become another negative side which certainly only complicates the online learning process for some groups of students. And finally, the results of the study also showed the unpreparedness of students in this distance learning process. This unpreparedness causes the effects of boredom, boredom, and psychological disorders due to the demands of different learning methods than usual.

\section{References}

[1] Tafsirweb, "Quran Surat Al-Mujadilah Ayat 11.".

[2] Tafsirweb, "Quran Surat At-Taubah Ayat 122.".

[3] H. Universitas Islam Negeri Alauddin Makassar, dan Djunaid, "Konsep Pendidikan Dalam Alquran (Sebuah Kajian Tematik)," Lentera Pendidik. J. Ilmu Tarb. dan Kegur., vol. 17, no. 1, pp. 139-150, 2014.

[4] "COVID-19 Dashboard by the Center for Systems Science and Engineering (CSSE)," Johns Hopkins University (JHU), 2020. .

[5] P. Hoi, S. C., Sahoo, D., Lu, J., \& Zhao, "Online Learning: A comprehensive Survey," 2018.

[6] M. Davies, J., \& Graff, "Performance in E-Learning: Online Participation and Student Grades," Br. J. Educ. Technol., vol. 36, no. 4, pp. 657-663, 2005.

[7] J. Bower, M., Dalgarno, B., Kennedy, G. E., Lee, M. J., \& Kenney, "Design and Implementation Factors in Blended Synchronous Learning Environments: Outcomes from a Cross-Case Analysis," Comput. Educ., vol. 86, pp. 1-17, 2015.

[8] H. D. Surjono, "Pemanfaatan Teknologi Informasi dan Komunikasi dalam Peningkatan Kualitas Pembelajaran," in Seminar MGMP Terpadu SMP/MTs Kota Magelang, 2010.

[9] R. Libbele, "ICT Policy Formulations and E-Strategy Development: A Comprehensive Guidebook," in UNDP Asia Pasific Development Information Programme, 2004.

[10] L. I. Meho, "Modeling the Information-Seeking Behavior of Social Scientists: Ellis's Study Revisited," J. Am. Soc. Inf. Sci. Technol., vol. 54, no. 6, 2003.

[11] Ardoni, Teknologi Informasi dan Perpustakaan, 1st ed. Jakarta: Sagung Seto, 2017.

[12] H. Meho, Lokman \& Tibbo, "Modeling The Information- Seeking Behavior of Social Scientists: Ellis's Study Revisited,” J. Am. Soc. Inf. Sci. Technol., vol. 54, 2003.

[13] P. R. and Reference, "Hedonic Theory." .

[14] O. Oladokun, "A Comparison of The Information Seeking Pattern of Distance Learners in Botswana: A Case Study of Four Tertiary Institutions," J. Libr. Inf. Serv. Distance Learn., vol. 4, no. 3, pp. 119-136, 2010.

[15] O. Oladokun, "Information Seeking Behaviour of The Off-Campus Students at The University of Botswana: A Case of Two Satellite Centers," J. Libr. Adm., vol. 50, no. 7/8, pp. 883-898, 2010 .

[16] S. Moyo, L., \& Ellysa, "Meeting The Needs of Remote Library Users," Libr. Manag., vol. 24, no. 6/7, pp. 281-290, 2003.

[17] H. W. Tang, Y., \& Tseng, "Distance Learners' Self-Efficacy and Information Literacy Skills," J. Acad. Librariansh., vol. 39, no. 6, pp. 517-521, 2013. 
[18] H. Umar, Metode Penelitian Untuk Skripsi dan Tesis Bisnis. Jakarta: Rajawali Pers, 2009.

[19] C. of Learning, "Guidelines on Distance Education during COVID-19," Creative Commons Attribution-ShareAlike 4.0 Licence. .

[20] B. Holmberg, Guided Didactic Conversation in Distance Education. In D. Sewart, D. Keegan, \& B. Holmberg (Eds.), Distance Education: International Perspectives. New York: St. Martin's Press, 1983.

[21] S. O, Supporting Student in Online, Open and Distance Learning. London: Kogan Page, 2002.

[22] T. Bainton, "Information Literacy and Academic Libraries: The SCONUL Approach," in Proceedings of the 67th IFLA Council and General Conference, 1625th August, 2001., 2001.

[23] D. F. \& I. Annisa, "Konsep Kecemasan (Anxiety) pada Lanjut Usia (Lansia)," Konselor, vol. 5, no. 2, 2016. 